\title{
Vida póstuma de um ilustre desconhecido: a cons- trução biográfica de Clóvis Beviláqua (1859-1944)
}

\author{
Wilton C. L. Silva \\ Universidade Estadual Paulista "Julio Mesquita Filho"
}

Introdução

Mesmo quando o biografismo é reduzido por quem o critica ou o exerce como um exercício de voyeurismo ou panteonização, com enfoque hagiográfico ou demonológico, não perde sua dimensão histórico-social em que diferentes narradores e auditórios se interessam por uma individualidade. ${ }^{1}$

A trajetória individual traduzida em narrativa coerente é desafiada pela existência de um amplo leque de motivações, acasos e contradições que caracterizam uma vida, assim como pela percepção de uma rede de relações de diferentes temporalidades, vínculos e pertencimentos que incidem sobre quem narra, o que se narra e para quem se narra.

O jurista Clóvis Beviláqua (1859-1944) ocupou posição privilegiada entre os 'brasileiros notáveis' do contexto de transição do século XIX para as primeiras décadas do século XX no Brasil, como membro destacado de uma elite política e intelectual, os bacharéis em Direito ${ }^{2}$, que desfrutava de uma importância ímpar em contraste com outros grupos profissionais e mais ainda em relação à imensa massa de iletrados da sociedade do período.

Como pessoa, intelectual e jurista, Clóvis Beviláqua vivenciou uma sociedade em transformação no campo político e cultural, seja na transição da Monarquia para a República, na dominação oligárquica e na Era Vargas, seja nos processos de codificação jurídica, ou ainda nas rupturas e continuidades do pré-modernismo para o modernismo, e nas vivências cotidianas de uma trajetória rica e intensa.

No campo jurídico, Clóvis Beviláqua foi professor na Faculdade de Direito de Recife, autor do Código Civil de 1917, consultor do Ministério 
das Relações Exteriores e jurista de prestígio internacional. Intelectualmente, foi crítico literário e autor de livros de direito, filosofia e história e, em termos privados, foi caracterizado por diversos amigos e contemporâneos como um exemplo de afetividade, generosidade e humildade, o que lhe valeu referência como 'santo laico'.

No entanto, as dinâmicas culturais e institucionais parecem caracterizar Clóvis Beviláqua como um ilustre e desconhecido jurisconsulto, autor fundamental na área de direito civil e internacional e da filosofia do direito, que referenciado como nome de logradouros, é esquecido como crítico literário, filósofo e indivíduo, sendo que suas obras não são reeditadas e seu nome não tem impacto fora dos círculos jurídicos. ${ }^{3}$

Desse personagem, tanto a memória cívica quanto a memória intelectual diluem-se ao longo do tempo, caminhando para o esquecimento, pois a primeira limitou-se a ser patrimônio de um limitado grupo profissional (os advogados), e a segunda vinculou-se à época em que foi produzida pela inexistência de instâncias de sua reelaboração através de instituições e grupos. ${ }^{4}$

Entre diversos textos, artigos e livros de natureza biográfica sobre o personagem, uma pequena biografia, lançada em 1989 em edição do autor, busca, de forma respeitosa e afetiva, traçar um retrato do biografado incorporando aspectos inéditos de sua vida privada.

A biografia Clóvis Beviláqua na Intimidade (1989), de Noêmia Paes Barreto Brandão, propõe-se a criar um retrato positivo do biografado, com o qual a autora confessa vínculos de respeito e afeto, ao mesmo tempo em que busca apresentar aspectos de sua vida privada a partir do acesso à sua correspondência familiar e ao depoimento de filhas e conhecidos. ${ }^{5}$

Dentro de uma perspectiva acadêmica, a obra, com 111 páginas e cerca de uma centena de notas de rodapé, apresenta diversos problemas: assumir um aspecto claramente laudatório, oscilando entre a 'literatura de paternidade' e o velho panegírico; utilizar de forma muito ampla fontes secundárias e não introduzir grandes novidades sobre a vida do biografado; e sucumbir aos problemas clássicos do biografismo brasileiro (o teleobjetivismo, a perspectiva hagiográfica, a ambição de verdade e a inevitável ordenação temporal).

Por outro lado, oferece uma perspectiva inovadora (a intimidade) e reafirma as bases consolidadas socialmente da memória do personagem, permitindo vislumbrar certa forma de historicidade das formas biográficas, 
tensões nos paradigmas do gênero e, principalmente, alterações na estrutura das relações de força simbólica que definem o campo intelectual num dado momento, de modo tal a sedimentar dimensões específicas de lembrança e determinadas formas de narrativa. ${ }^{6}$

Intimidade e monumentalidade: o Clóvis Beviláqua de Noemia Paes Barreto Brandão

A biografia Clóvis Beviláqua na intimidade, de Noemia Paes Barreto Brandão, justifica-se ao oferecer uma abordagem da intimidade do biografado a partir da recuperação da memória das filhas (Veleda e Floriza ${ }^{7}$ ) e de pessoas próximas a respeito do biografado. ${ }^{8}$

$\mathrm{Na}$ introdução, a autora ressalta a "grande responsabilidade" de escrever sobre "homem público do quilate de Clóvis Beviláqua", definindo-o como "figura sagrada” e exemplo de "fé no Direito, na Família e na Pátria”, e qualificando seu livro como contribuição espontânea, respeitosa, admirativa e carinhosa ao "gigante do Direito". ${ }^{10}$

Historiograficamente, o livro pouco acrescenta, uma vez que a imensa maioria das informações procede de material de fontes secundárias de fácil acesso, e o texto mantém o tom apologístico de discursos solenes e eventos memorialísticos.

Sua relevância, por outro lado, é a introdução de algum material do acervo particular da família e a proposta de uma abordagem intimista sobre alguns momentos da vida do personagem.

A estrutura narrativa, de forma pendular, oscila entre a divisão temática e a ordem cronológica, possuindo nove capítulos, intitulados: Traços do temperamento, A vida em família, Primórdios, Juventude acadêmica, Funções na vida pública, Honrarias e homenagens, Velhice, Falecimento e Centenário de Nascimento, constando ainda de uma centena de notas de rodapé e de uma bibliografia ao final. ${ }^{12}$

Em linhas gerais, a obra estrutura-se da seguinte forma: Traços de temperamento narra eventos que demonstram o romantismo, a bondade e os vínculos de amizade do jurista; $A$ vida em família disserta sobre o relacionamento com a família Freitas e com a esposa, sendo as filhas o foco do capítulo; Primódios informa sobre os ancestrais, a infância e a vida escolar; Juventude acadêmica 
descreve a vivência na Faculdade de Direito de Recife, a opinião de colegas e as ideias filosóficas; Funções na vida pública aborda as diversas funções exercidas pelo biografado; Honrarias e homenagens avalia a repercussão de sua obra; Velhice relata as atividades intelectuais, os hábitos e os achaques nessa fase da vida; Falecimento tece considerações sobre o funeral; e Centenário de nascimento lista eventos na efeméride.

Segundo Brandão ${ }^{13}$, o romantismo de Beviláqua é demonstrado pelos versos que fez na juventude e a admiração expressa por José de Alencar e Castro Alves. A autora cita cartas do arquivo familiar em que são comentados os versos, mas principalmente a forma como conviveu com a esposa, Amélia Carolina de Freitas Beviláqua.

Como detalhe curioso, cita Brito Bugyja, que informara a predileção inicial, platônica de Clóvis pela irmã mais nova de Amélia, Ana Julieta, assim como a interferência do futuro sogro para que a filha mais velha fosse a escolhida. ${ }^{14}$

Trechos de cartas de amor e poemas são citados (a autora classifica o biografado de "poeta bissexto" ${ }^{15}$ ), frisando que eram documentos "de que o público não teve conhecimento" e que representavam a "pureza" e a "delicadeza" de um afeto dedicado à sua esposa, com quem manteve um convívio de sessenta e um anos de amor, amizade e companheirismo intelectual. ${ }^{16}$

Sobre o companheirismo intelectual, narra a polêmica que envolveu o casal após Amélia buscar lançar sua candidatura à Academia Brasileira de Letras em 1930 e ter seu pleito recusado pela instituição por seus estatutos afirmarem ser ela destinada "aos brasileiros", o que significaria a exclusão das "brasileiras" (14 votos contra 7, em sessão de 29 de maio daquele ano), o que levou Clóvis a escrever um artigo no Jornal do Comércio (de 08 de junho) intitulado Inelegibilidade de Senhoras para a Academia Brasileira de Letras, que classificava a decisão de "absona" (dissonante), irracional, injusta e conservadora, o que fez com que, a partir desse incidente, não mais frequentasse a instituição (da qual participara da fundação, em 1897). ${ }^{17}$

Em carta de Clóvis Beviláqua a Laudelino Freire, o jurista identifica, na recusa da candidatura, a falta de civilidade que "devia merecer a atenção e o tratamento dedicado, a que tem direito, como escritora e como mulher da sociedade". Amélia também publicou o opúsculo A Academia Brasileira de Letras e Amélia Beviláqua, no qual critica a decisão dos "imortais misoginistas", 
ainda chamados de "maçonaria das letras", e anexa críticas de diferentes escritores e intelectuais ao posicionamento da instituição. ${ }^{18} 19$

Sobre a bondade de Clóvis, afirmada em diversas biografias, o que ensejou a comparação com São Francisco de Assis, são elencadas diversas situações de significativa generosidade, assim como outras de acentuada correção ética, todas relatadas a partir de terceiros, em situações de homenagem. ${ }^{20} 21$

As amizades seriam demonstradas pela correspondência do jurista com amigos de longa data (Silva Jardim e Martins Júnior) e notáveis com maior intimidade, como José Maria da Silva Paranhos - o Barão do Rio Branco, ou com relações mais formais, como Rocha Pombo, Rui Barbosa, Spencer Vampré, entre outros. ${ }^{22}$

A quantidade de cartas elencada por Brandão não impressiona pelo seu número, mas com certeza é um exemplo raro da rede de relações que o jurista mantinha, tanto no campo profissional como no pessoal, em correspondência emitida e recebida em tom de exaltação, enaltecimento, cordialidade, amizade e, em alguns casos, intimidade. ${ }^{23}$

Em $A$ vida em família, o aspecto heróico do encontro de Clóvis Beviláqua com a família de Amélia em praia de Olinda, quando ele retira a família ameaçada de afogamento das águas do mar, é citado e o contraste de situação social entre o humilde jovem advogado e a primogênita de 10 filhos de um importante desembargador e presidente de província é superada facilmente pela grandeza de caráter do pretendente.

Também é feita referência a Amélia como "extrovertida, inteligente e (que) já demonstrava pendores literários" ${ }^{24}$ - fora redatora da revista Lyrio, que Brandão afirma ter sido a primeira revista nacional de senhoras, editada em Pernambuco. ${ }^{25}$ Ela é descrita como baixa, com olhos e cabelos pretos, morena e magra, alegre, inteligente e simpática, tendo recebido boa educação e oportunidade de convívio doméstico com intelectuais e políticos. ${ }^{26}$

A família manteve professores particulares para as filhas, frequentava cotidianamente restaurantes (o Brahma, o do Hotel Avenida, no qual jantavam todos os dias, e a Confeitaria Colombo) e, nos fins de semana, recebia diversos convidados:

Aos domingos, parentes, amigos, juristas, estudantes de Direito iam à sua casa pelo prazer do bom convívio. A cordialidade dos anfitriões 
dava calor às reuniões. Mesa farta, vinhos de excelente qualidade e em profusão. A mesa era renovada várias vezes ao dia, tantas as pessoas que chegavam. ${ }^{27}$

A perspectiva íntima da narrativa mostra-se, por exemplo, na descrição que faz a autora de visita feita à casa do biografado, quando era ainda uma criança, nos idos de 1940. Ela descreve a forma de vestir do casal (formal e modesta), o mobiliário de sua casa na Tijuca, as filhas, os animais de estimação da família (um galo chamado Sassarico e dois cães, Eolo e Felizardo) e os cuidados de Clóvis com a esposa (que sofria de surdez e esclerose) ${ }^{28}$, percebido no apelido pelo qual o marido a chamava, 'Miloquinha'29, sendo que esta referia-se a ele como 'o Mestre'. A autora observa ainda que o jurista apreciava 'arroz de pequi', prato da culinária piauiense, que tocara flauta na juventude, era forte e exímio nadador, e que não fumava nem jogava, e só bebia nas refeições (vinho ou champanhe). ${ }^{30}$

Em Primórdios, sobre as origens familiares de Beviláqua, aparece referência aos avós, sendo os homens de origem italiana e portuguesa, e as mulheres de origem brasileira, havendo ligações com a nobreza italiana, além do fato conhecido, mas delicado, de que seu pai, José Beviláqua, era vigário da Paróquia de Viçosa (CE).$^{31}$

Sobre a infância, abordada em parte específica, somente se afirma o temperamento tímido de um filho de pais austeros, e que desenvolveu tal característica de sua personalidade como reflexo da condição de 'filho de padre' em uma sociedade moralista e preconceituosa. ${ }^{32}$

A vida escolar, por sua vez, tem inevitáveis notas sobre a predestinação ao conhecimento e o caminho percorrido no processo de formação até a Juventude Acadêmica, tema de parte específica da obra, que retrata a formação na Faculdade de Direito de Recife em meio à agitação da geração de 1870 que, influenciada por Tobias Barreto, participava em jornais, defendia a República e se dedicava com afinco às discussões literário-filosófico-jurídicas, cuja ampla agenda contemplava:

Positivismo, evolucionismo, darwinismo, crítica religiosa, naturalismo, cientificismo, na poesia e no romance, folclore, novos processos de crítica e de história literária, transformação de instituição de 
direito e de política, tudo então se agitou e o brado de alarme partiu da escola do Recife... ${ }^{33}$

Em O Filósofo - seus pensamentos, a influência de Comte, Littré, Haekel, Spencer e Von Jhering são apontadas ${ }^{34}$, assim como a postura ateia e o convívio pacífico com o catolicismo da esposa e das filhas. ${ }^{35}$

Destaca-se, na abordagem biográfica de Brandão, a sedimentação da memória de Clóvis Beviláqua, ou seja, o que se disse a respeito do jurista, sua obra e sua vida, de modo tal que a imensa maioria das informações são mediadas pelo olhar do outro, por fontes secundárias, sem a devida crítica, inclusive - daí a adjetivação, o monumentalismo e a sacralização nas descrições. ${ }^{36}$

A descrição das Funções na vida pública mantém o mesmo padrão, um recorte de citações de trechos de discursos comemorativos, artigos laudatórios e narrativas apologéticas do promotor, do bibliotecário, do professor, do político, do jornalista, do escritor, do jurista ${ }^{37}$ e do consultor Clóvis Beviláqua ${ }^{38}$, com destaque para as diversas associações a que se filiou no Brasil e no exterior ${ }^{39}$.

Também Honrarias e homenagens apresenta diversos excertos de textos alheios sobre o desapego (ou mesmo desinteresse) do jurista por cargos (como as recusas em ser deputado, senador, governador do Ceará, em 1890; Delegado do Brasil no Congresso Americano, em 1906; Ministro do Supremo Tribunal Federal, em 1912, 1920 e 1929; membro da Comissão de Juristas que preparariam o Anteprojeto de Organização da Corte Permanente de Justiça Internacional, em 1920; entre outros) e enumera diversas salas, bibliotecas, bustos, cursos e praças que receberam seu nome. ${ }^{40}$

Em Velhice, a autora descreve como, mesmo aposentado compulsoriamente aos 75 anos do cargo de Consultor Jurídico do Ministério das Relações Exteriores, em 1934, continuou a atividade jurídica e intelectual. Nessa parte do texto, nos subitens intitulados Hábitos e Achaques, o biografado ganha dimensões rotineiras, prosaicas: o idoso que levanta cedo; não sai de casa; come pouco; não aprecia carne, mas se delicia com doces e passa os dias de pijama; o ancião que sofre de erisipela ${ }^{41}$, angina ${ }^{42}$ e problemas cardíacos. ${ }^{43}$

O jurista faleceu em 26 de julho de 1944, aos 84 anos, e sua morte despertou diversas manifestações de pesar e reverência. Ele morreu pobre e deixando um legado de reconhecimento público, reafirmado de forma ampla em seu Centenário de Nascimento, em 1959..4 
Brandão faz referência ao consumo de conhaque pela viúva após a morte do marido, assim como às necessidades econômicas enfrentadas pela família após o falecimento do jurista. ${ }^{45}$

Três estigmas: marcas de uma biografia

As biografias de Clóvis Beviláqua apresentam três temas que são cercados de tensões, cuidados e pruridos: a origem do jurista como 'filho de padre'; a relação com a esposa, Amélia Beviláqua; e a polêmica com Rui Barbosa na codificação civil.

Como o livro de Brandão ambiciona abordar a intimidade do jurista, tais temas se fazem presentes de forma inevitável e as soluções encontradas pela autora servem de exemplo da forma como tais estigmas foram abordados por biógrafos anteriores.

\section{A) O FILHO DE PADRE}

A condição de filho de um padre, portanto concebido fora da instituição do matrimônio, não era rara no Brasil do século XIX, o que se comprova por volumosa documentação que originou, por sua vez, farta bibliografia sobre o tema. ${ }^{46}$

Um tipo de documentação privilegiada para a percepção de tal realidade são os testamentos de padres que citam seus filhos ilegítimos como herdeiros de seus bens, trazendo uma riqueza de detalhes bastante particular, uma vez que, diferentemente do inventário que é circunscrito à descrição de uma situação material, este apresenta minúcias não só sobre a origem e os nomes dos pais do testador, mas também sobre relações familiares e vínculos afetivos.

Alguns estudos afirmam que no período colonial o casamento era uma opção difícil para a maioria da população, pelas exigências burocráticas e financeiras, assim como pela limitação, pelo registro eclesiástico, de vínculos entre parentes de até quarto grau de consanguinidade, sendo que tais condições favoreciam o concubinato.

O concubinato, nesse contexto, surgia como reflexo de uma sociedade marcada pela instabilidade e precariedade de uma situação de exclusão por ausência de bens ou recursos para a manutenção de uma vida conjugal dentro 
dos padrões das elites locais, o que criou um hábito que também se manifestava entre os padres que não se submetiam ao celibato. ${ }^{47}$

O celibato clerical, afirmado pelo Concílio de Trento, não encontrou respaldo em número significativo do clero no Brasil, e mesmo o episcopado mostrou-se tolerante com aqueles membros da Igreja que transgrediam a norma. ${ }^{4849}$

Mulheres das classes populares encontravam no vínculo afetivo-sexual certa estabilidade econômica e ascensão social, sendo que suas proles teriam oportunidades maiores do que a imensa maioria dos brasileiros no período. ${ }^{50}$

Até meados do século XIX, as relações do Estado com a Igreja, assim como os esforços da instituição religiosa para uma defesa intransigente do celibato, não impediram a existência de relações de concubinato nem entre laicos nem quando envolvia religiosos (que se justificavam com a alegada “fragilidade humana”), e a determinação do Concílio de Trento manteve-se no Brasil mais como ficção do que como realidade.

Diversos homens de prestígio na política e na literatura ostentaram o estigma de 'filhos de padre', como José de Alencar (cujo pai - o senador José Martiniano de Alencar - viveu maritalmente com uma prima, Ana Josefina, com quem teve oito filhos), José do Patrocínio (filho de uma jovem quitandeira chamada Justina e do pároco da capela imperial, João Carlos Monteiro - que não lhe reconheceu a paternidade, mas encaminhou-o), Diogo Antônio Feijó (batizado como 'filho de pais incógnitos', mas que, segundo alguns pesquisadores, seria filho do vigário Manuel da Cruz Lima) ${ }^{51}$, Teodoro Fernandes Sampaio (filho de uma escrava com o sacerdote Manuel Fernandes Sampaio, que lhe comprou a alforria e cuidou para que o menino tivesse uma boa educação), entre outros.

Somente a partir do fortalecimento das posições tradicionalistas no interior da própria Igreja, dentro do centralismo e uniformalismo ultramontano, no final do século XIX, é que o concubinato envolvendo eclesiásticos passa a ser efetivamente combatido e identificado socialmente como tabu.

O Estado Republicano, separado da Igreja, mas adotando uma perspectiva de modernização civilizatória, busca adequar as instituições públicas e privadas aos padrões culturais europeus, sendo fundamental o controle sobre a conduta moral, a saúde, a vida sexual dos casais e dos solteiros e, por conseguinte, o repúdio a qualquer forma de concubinato. 
O jurista cearense, inclusive, "não escondia o fato (de ser filho de padre) para os íntimos - na parede de seu quarto de dormir conservava o retrato do pai vestido de batina". 52

Teria sido interessante que Brandão ${ }^{53}$ houvesse mantido os pronomes de tratamento na transcrição feita de trechos de duas cartas do pai para Clóvis Beviláqua, pois mostraria não só a preocupação no cuidado paterno com o futuro do filho, mas também a forma que a intimidade assumia entre ambos.

De certa forma, a figura de Clóvis Beviláqua incorpora diversas tensões desse contexto de transformações políticas e culturais: filho de padre criado em uma situação de relativa tolerância e usufruindo das vantagens dessa situação, republicano e positivista refratário à Igreja enquanto instituição e desejoso de uma ordem política e social modernizante e civilizatória para o país, pai que foi levado pelos preconceitos de sua época a assumir como suas as filhas de sua filha, e pensador e jurista sensível às questões sociais (entre as quais a questão dos filhos ilegítimos).

Esse leque de condicionantes impede qualquer reducionismo sobre sua personalidade e seus atos, merecendo destaque seu projeto do Código Civil, que constava com disposições inovadoras e liberais sobre trabalho doméstico, filiação natural, situação da mulher, casamento entre outras questões - diferente do texto aprovado após mais de uma década de embates legislativos.

\section{B) A ESPOSA EXÓTICA}

O segundo tema sobre o qual a biografia de Clóvis Beviláqua desperta pudores na narrativa é o papel de sua esposa, Amélia Carolina de Freitas Beviláqua, que adotava modos excêntricos frente à sociedade da época, e que lhe renderam diferentes imagens construídas: escritora arrivista que ambicionou entrar para a Academia Brasileira de Letras; dona de casa relapsa, que permitia que animais domésticos habitassem no interior da residência; mulher pouco vaidosa e desalinhada no vestir; esposa leviana ou adúltera, entre outras adjetivações negativas.

Clóvis descreveu a esposa da seguinte forma: 
Franzina e delicada de formas, sem que os traços da carnação percam as curvaturas amplas em que se desenham as graças da feminilidade. Olhos pretos em tez morena, cabelos longos, cabeça pequena assentada sobre umas espáduas que se afiguram mais longas pela exigüidade da cintura, boca bem talhada e dentes muito alvos. Nariz de traços corretos e afilado. Rosto oval e muito levemente polpudo. (...) Interiormente, o retrato moral se faz de duas palavras: um coração amoroso e terno e uma inteligência clara e voltada para o bem. ${ }^{54}$

Segundo Falci ${ }^{55}$, a memória da esposa do jurista foi mantida da seguinte forma:

Amélia de Freitas Beviláqua é lembrada, ainda hoje, por pessoas já de certa idade que com ela conviveram no Rio de Janeiro nas décadas de trinta e quarenta do século XX por apresentar atitudes 'modernistas' de vanguarda, consideradas até um tanto ou quanto amalucadas. Lembrada como dona de casa excêntrica, onde os animais domésticos disputavam espaços nos sofás e poltronas, onde a banheira servia como ninho para galinhas em choco e onde os pombos e galos voavam por sobre as cabeças dos visitantes; ou como desalinhada e de mau aspecto sob o ponto de vista físico; lembrada ainda como de comportamento avançado sob o ponto de vista moral; muitos esquecem o valor literário que Amélia possuiu. ${ }^{56}$

Brandão, em algumas passagens, refere-se a aspectos controversos ou indesejados de Amélia, como a vaidade:

A família de Beviláqua era simples em tudo, no linguajar, no vestir, nos hábitos alimentares. Não tinha vaidades. É certo que Amélia na mocidade era vaidosa. Usou sempre chapéu e fazia papelote para encrespar os cabelos. Com a idade relaxou. ${ }^{57}$

A autora comenta, ainda, sobre a bebida, quando afirma que após a morte de Clóvis Beviláqua a viúva consumiu treze garrafas de conhaque entre julho e outubro de $1944 .{ }^{58}$ 
A adjetivação sobre Amélia pode ter diversas origens, que nascem da misoginia ou do conservadorismo do período: a autonomia de Amélia como mulher, sua qualidade como literata, o tipo de obra construído pela autora, sua audácia em se candidatar à Academia Brasileira de Letras, entre outras.

O próprio Clóvis Beviláqua, em 1878, criticava de forma enfática o modelo de educação das mulheres no Brasil do século XIX, apontando o seu reflexo sobre a literatura feminina de então:

a mulher brasileira, influxionada pelo meio ambiente e por uma educação mal dirigida, tem uma vida indolente, contemplativa, molificante e é inapta para o augusto mister de educadora de seus filhos, o que origina a nossa aversão para o trabalho.(...) Com a direção mental, a que geralmente se submetem as mulheres que em nosso país têm uma educação intelectual, com a sua sujeição inevitável à lei do atavismo, (...) aqui as mulheres serão somente poetisas e poetisas voluptuosas, plangentes e desoladas. ${ }^{59}$

Como autora de romances, novelas, contos e artigos, e colaboradora na fundação e edição de revistas literárias e livros, Amélia Beviláqua mostrou-se senhora de um pensamento crítico sobre as questões de estética e de gênero.

A questão de gênero, em um desses momentos opinativos, é tratada em seu livro Impressões com um capítulo intitulado Divórcio, no qual argumenta que:

a união de dois seres pelo casamento só se deveria dar pelo amor, nunca pelos interesses materiais e familiares mas como se manter uma união onde não existe respeito mútuo, afeto e atenção? Como a alma feminina poderia se manter tranqüila e feliz? Ela conduz o discurso e o pensamento de modo a se pensar que ela tem a independência das feministas. No entanto, no decorrer da entrevista, ela usa de artifícios. Quando se pensa que ela afirmaria com toda a força de seu pensamento a necessidade do divórcio, ela, muito inteligentemente, numa época ainda impregnada de preconceitos, faz a apologia da família bem constituída e da união pelo bem dos filhos. ${ }^{60}$ 
Em outro momento, quando entrevistada pelo o jornal $A$ Noite sobre se a mulher poderia participar em um júri forense, ela respondeu:

Stuart Mill, Bridel e muitos estrangeiros foram sempre partidários da elevação da mulher, alguns foram mesmo fanáticos... Ao menos, isso vinga e suaviza as impertinências de Schopenhauer e de Lombroso, que duvidava tanto do sexo delicado, e não o julgava absolutamente capaz de imaginação criadora e produções originais. (...) Apesar de tantas oposições as coisas tomaram os caminhos da justiça e da razão. As mulheres que agora são simplesmente eleitoras em breves dias subirão talvez à Câmara, ao Senado, aos ministérios e quem sabe? Às interventorias. Se elas podem galgar todos esses postos e já estão designadas, segundo me informaram, para a elaboração da futura carta constitucional, por que, pergunto eu, não entrarão elas também no júri em que se apura e depura a reação da sociedade contra o crime? ${ }^{61}$

Com certeza, as ambições literárias de Amélia Beviláqua eram maiores do que a poesia voluptuosa, plangente e desolada que o marido condenara, sendo que o tom ensaístico e confessional de uma de suas obras, Contra a sorte de 1938, parece desafiar os padrões estéticos da época, dotando a narradora de sensualidade e desencanto:

(...) $\{$ mantenho $\}$ a lembrança do prazer misterioso que eu sentia de viver, de amar loucamente e multiplicar minha vida para Ter a grande ventura de ainda amar muito mais. (...) Dos sonhos que me perderam, não encontrei mais um traço dentro de mim mesma. O meu coração exorcizado, sem mais afetos, retornou ao nada, ao século da liberdade cativa. Escuto os gemidos do meu paraíso, (...) baixo a cabeça - era o último rendez-vous comigo mesma, dentro do meu paraíso perdido. ${ }^{62}$

A autora com certeza era uma mulher inteligente que se permitia ser 'coquette', quando usava de humor, elegância e provocação, como em abertura de conferência do Terceiro Congresso Scientífico Latino-Americano, realizado no Rio de Janeiro, em agosto de 1905, quando ela tinha 44 anos e afirma que falará para não parecer preguiçosa; ou ainda em palestra de 1931, com 
70 anos, no início do governo Vargas: "Estão em discussão o voto feminino, os direitos civis e políticos, a quebra do padrão da moeda na Inglaterra, as decadências financeiras no Brasil. Tudo isto já está enfadonho." ${ }^{3}$

Esse comportamento audacioso lhe valeu críticas diversas, sendo a mais grave a acusação de adultério.

Maia ${ }^{64}$ publicou uma biografia, entre tantas outras surgidas no centenário do jurista, em que afirmava no prefácio que era obra "sem caráter crítico ou analítico, mas no evidente sentido panorâmico e panegírico", ambicionando desenvolver um "espírito mais interpretativo do que de pesquisa" e "nada revelando de novo biograficamente terá destacado motivos de ordem secundária, todavia significativos".

Embora o autor reafirme o caráter beatífico de Clóvis Beviláqua, pondera que não abordará a sua vida íntima "para não sermos desprimorosos, poupar-lhe-emos a venerável e admirável memória". ${ }^{65}$

No entanto, sobre a esposa faz referência à suposta forma imprópria para a idade com que se vestia e utiliza-se do termo "indiscrições" para qualificar situação delicada envolvendo a escritora e um terceiro.

Segundo o autor, Dulcídio Gonçalves, delegado e ex-aluno do jurista, avisa-o sobre situação envolvendo Amélia, um outro homem e certa quantia em dinheiro que este recebera desta, o que despertou veemente defesa do jurista, enfatizando que não aceitava a caracterização de sua esposa como irresponsável ou instável.

Indiferente ao fato de que tal transação pudesse ser originada por dádiva ou extorsão, Maia ainda aponta ${ }^{66}$, em referência direta ao adultério, o contraste entre a personalidade de Clóvis Beviláqua e o 'modelo nortista', do qual Euclides da Cunha seria um exemplo.

Essa referência a uma suposta tolerância de Clóvis Beviláqua ao adultério da esposa, mais do que originada pelos fatos, pode ser desdobramento do comportamento 'moderno' desta, que se somava à posição intelectual daquele durante os debates sobre o Código Civil, em que defendia existir igual gravidade no adultério tanto masculino quanto feminino, por ambos caracterizarem quebra da fidelidade conjugal recíproca exigida pela lei, ao contrário de outros juristas, que culpabilizavam mais a mulher adúltera: 
Alguns escritores, ainda imbuídos do preconceito da superioridade do homem, a quem se permite abusos e desregramento, como o senhor das posições sociais, insistem em mostrar que o adultério da mulher é indício de depravação maior, e que produz conseqüências as mais graves, porque pode introduzir na família filhos estranhos. A primeira observação é falsa, porque se a sociedade exige da mulher o maior recato, deve, igualmente, exigir do homem que não quiser ser tule com o espetáculo de sua imoralidade, porque o dever da fidelidade é recíproco. Se, ao casar-se, um homem fizesse a declaração de que não aceitava para si a obrigação de se manter fiel, não encontraria pai honesto que lhe confiasse a filha. A segunda observação não é mais convincente do que a primeira. $\mathrm{O}$ adultério da mulher pode introduzir na família um estranho; mas, em regra, e são a facilidade do marido que incitam a mulher aos desvios, e a questão não deve ser posta nesses termos. Não se trata de medir a conseqüência da infidelidade... E, encarados os fatos do ponto de vista ético, não são menos imorais as ribaldarias amorosas do marido do que a desonestidade da mulher. ${ }^{67}$

Outras biografias, Brandão entre elas, frisam a proximidade do casal e os laços de afetividade que se mantiveram ao longo do tempo, portanto, sem nenhuma referência documental a qualquer episódio dessa natureza, tal afirmativa se soma a outros preconceitos misóginos que uma personalidade como a de Amélia Beviláqua deveria provocar em alguns de sua época.

\section{C) O CÓDIGO CIVIL}

Finalmente, sobre a polêmica no Código Civil, quando Rui Barbosa despejou pesadas críticas ao projeto de Clóvis Beviláqua, dando início a uma polêmica que envolveu juristas, intelectuais, políticos e instituições (o Supremo Tribunal Federal, as diversas faculdades de Direito e o Instituto da Ordem dos Advogados, entre outras), a abordagem de Brandão não acrescenta nada de original, restringindo-se a historicizar a contenda a partir de diversas fontes secundárias. ${ }^{68}$ 
Avaliações da ação de Rui Barbosa como paladino do purismo gramatical e do resguardo da linguagem jurídica na redação da obra permitiram diversas abordagens por diferentes autores. ${ }^{69}$

A polêmica entre Rui Barbosa e Clóvis Beviláqua apontava para uma tensão literária no interior do discurso jurídico, em que se faziam presentes o purismo linguístico e a defesa do discurso legislativo como patrimônio dos iniciados na linguagem forense. O jurista baiano critica Clóvis Beviláqua por ser inexperiente juridicamente e não possuir o domínio da "ciência da sua língua, a vernaculidade, a casta correção do escrever", enquanto Carneiro Ribeiro, embora professor de línguas, era "profano em coisas jurídicas".

$\mathrm{Na}$ defesa de seu texto, Clóvis Beviláqua reafirma a tensão entre ordem jurídica e linguagem, identificando nos conhecimentos jurídicos o alicerce do Código Civil pela sua orientação doutrinária, mais do que os conhecimentos gramaticais.

O Código Civil, de 1916, recebeu tradução para o francês e o alemão, sendo reconhecido como modelo de clareza e boa técnica e vazado em orientações provindas do liberalismo político e econômico, mas já com certo sentido social (por exemplo, ao regular a locação de serviços, mostrou a conveniência de vir o direito do trabalho a constituir matéria de lei especial, enquanto no campo do direito de família, admitiu o reconhecimento dos filhos ilegítimos e a investigação de paternidade).

Como o eixo da biografia citada é a intimidade de Clóvis Beviláqua, a polêmica pública não ganha maior destaque e Brandão ${ }^{70}$ reafirma, através de numerosas citações, a avaliação positiva do resultado final da codificação, enaltecendo o jurista cearense como seu artífice.

\section{Considerações Finais}

No livro de Noemia Paes Barreto Brandão, a memória cívica e intelectual e a intimidade ligam-se a partir da reafirmação de aspectos socialmente construídos pelos apologistas do 'santo laico' ao longo das décadas anteriores, e os estigmas são reinterpretados.

A origem de filho de padre convive com a linhagem supostamente aristocrática, o vínculo afetivo entre pai e filho e a situação semelhante de outros notáveis; a falta de preparo intelectual é descartada pela autoria da 
codificação civil e a dedicação ao trabalho; e as sutilezas da relação com a esposa diluem-se no tempo de convivência, nas demonstrações de afeto, na lealdade intelectual.

O livro, quer por seus méritos, quer por suas limitações, permite-nos pensar a função da obra biográfica enquanto forma particular de memória e oferece três questões que nos parecem dignas de reflexão.

A primeira deriva da constatação de que a existência de uma biografia supõe a ampla utilização de forças sociais pela manutenção de uma memória ou de um certo tipo de memória, na qual um indivíduo é não somente uma unidade, mas parte de um grupo e representação de ideais e expectativas que já não são subterrâneas, mas que convivem junto a outras manifestações de superfície.

Isso é demonstrado pela quantidade significativa de fontes secundárias utilizadas pela autora, que materializam o esforço pela conservação ou utilização do personagem e de sua trajetória como exemplo, inspiração e legitimação grupal. ${ }^{71}$

A segunda é desdobrada da constatação da perspectiva narrativa da autora, em que esse indivíduo, encarado como notável, e descrito em sua dimensão íntima e pessoal, é visto como diferenciado dentro do grupo e da sociedade da qual faz parte.

E, por último, mas não menos importante, a percepção de que o biografismo é um objeto propício para se constatar a multiplicidade de significados e expectativas que uma mesma matéria narrativa, uma trajetória individual, pode assumir em diferente obras/autores/épocas.

A distribuição temporal da produção de biografias de Clóvis Beviláqua, com predominância das datas de sua morte e de seu centenário, assim como a forte presença de relatos memorialísticos nesses textos, remetem inevitavelmente aos processos de canonização e mitificação que se projetam a partir da construção de um vínculo de pertencimento quando, em linhas gerais, literatos falam do literato e juristas falam do jurista, na explicitação de vínculos, amizades e afinidades eletivas. ${ }^{72}$

Assim, identificar a biografia como construção histórica e social diz respeito a discuti-la como espaço de disputa da memória e de materialização do passado enquanto patrimônio e lugar de memória - principalmente no processo de identificação e legitimação entre certos indivíduos e grupos. 


\section{Notas e Referências}

1 Texto que faz parte dos resultados parciais de pesquisa homônima que recebe recursos do CNPq.

2 Cabe aqui lembrar que, segundo algumas simplificações esquemáticas, o grupo profissional apresentava uma distinção interna entre a perspectiva intelectualizada das elites jurídicas formadas em Recife e a perspectiva pragmática, política e forense, mais presente nos formados em São Paulo.

3 Em trabalho anterior (Wilton C. L. SILVA. "Biografias em contraste: memória e desmemória em Ruy Barbosa e Clóvis Beviláqua”. In: Anais do IV Simpósio Nacional de História Cultural. Goiânia, 2008.), buscamos contrastar a memória de Ruy Barbosa e Clóvis Beviláqua a partir de levantamento bibliográfico realizado pelo Centro de Documentação do Pensamento Brasileiro, no Dicionário Biobibliográfico de Autores Brasileiros, identificando obras sobre eles ou suas ideias e realizações e, no caso do jurista cearense, constatou-se que foi autor de 51 livros e tema de 31 obras, das quais $1 / 3$ foi produzido no ano de sua morte (1944) e 3/4 durante o seu centenário (1959).

4 A memória de Clóvis Beviláqua nos meios jurídicos foi preservada em grande parte pela longevidade do Código Civil elaborado por ele, sendo que, entre as décadas de 20 a 40, consolida-se sua imagem como grande jurista, ao mesmo tempo em que os bacharéis passam a identificá-lo como símbolo do liberalismo jurídico, em substituição a Rui Barbosa, já falecido.

5 Nem de longe o texto de BRANDÃO, Clóvis Beviláqua na intimidade. oferece o nível de detalhamento ou intimidade de um modelo clássico brasileiro desse tipo de abordagem: "Machado de Assis, páginas de saudade" (1910), ensaio de Mário ALENCAR, filho de José de Alencar que, como jovem poeta, trocou inúmeras cartas com o fundador da Academia Brasileira de Letras e, a partir dessa correspondência, montou um inspirado relato memorialístico. A voz da narradora aparece em pouquíssimas ocasiões na descrição da vida do jurista, os trechos de cartas utilizados são em sua maior parte já conhecidos, e a originalidade se dá pelo acesso a alguns documentos familiares, mas sem nenhuma revelação bombástica (como no caso do ensaio citado em que, em trecho de carta, Machado de Assis assume o aspecto biográfico do "Memorial de Aires", por exemplo).

6 No projeto de pesquisa Vida póstuma de um ilustre desconhecido: a construção biográfica de Clóvis Beviláqua (1859-1944), propomo-nos a analisar a forma 
da construção biográfica a partir de três obras distintas sobre o jurista: Raimundo MENEZES e Ubaldino de AZEVEDO. Clóvis Beviláqua. São Paulo: Martins, 1960, Noemia Paes Barreto BRANDÃO. Clóvis Beviláqua na intimidade. 1989 e Silvio Meira MEIRA. Clóvis Beviláqua: sua vida, sua obra. Fortaleza: Edições Universidade Federal do Ceará, 1990, na busca de perceber a relação entre a historicidade das formas biográficas e as mudanças operadas nos paradigmas do gênero e, principalmente, as alterações na estrutura das relações de força simbólica que definem o campo intelectual num dado momento. (Maria Helena WERNECK. O Homem Encadernado: Machado de Assis na escrita das biografias. Rio de Janeiro: EdUERJ, 1996, p.25.

7 O casal teve cinco filhas: Floriza, Dóris, Thereza (falecida aos 4 meses), Veleda e Vitória, sendo que, na verdade, as três últimas eram filhas de Floriza, que se separara do marido. O casal também criou um sobrinho de Clóvis, Aquiles Beviláqua.

8 Brandão foi utilizado amplamente em trabalho de Gislene NEDER. Amélia e Clóvis Bevilacqua: o casamento, o casal e a idéia de indivíduo. In: Anais X Encontro Regional de História da ANPUH. UERJ, Rio de Janeiro, 14 a 18 de outubro de 2002, sobre o casamento, o casal e a ideia de indivíduo a partir de considerações sobre a relação de Amélia e Clóvis Bevilacqua (sic) e a codificação civil.

9 Embora existam diversas obras sobre o jurista, com destaque para a memória jurídica reforçada em diversas publicações da área, Noemia Paes Barreto BRANDÃO. Clovis Bevilacqua na intimidade. Rio de Janeiro: edição da autora, 1989, p. 8 identifica, na sua introdução, a biografia de Raimundo MENEZES \& Ubaldino de AZEVEDO. Clóvis Beviláqua. São Paulo: Martins, 1960 como fonte secundária privilegiada. O texto de MENEZES \& AZEVEDO, vitorioso em um concurso público de biografias sobre o jurista, vincula-se ao modelo documentarista, afastando-se claramente da biografia romanceada, com busca significativa de fontes que corrijam, confirmem ou ampliem a memória já estabelecida do biografado.

10 Noemia Paes Barreto BRANDÃO. Clovis Bevilacqua na intimidade. Rio de Janeiro: edição da autora, 1989, p. 7-8.

11 As notas de rodapé carecem de precisão acadêmica, sendo, na maioria das vezes, imprecisas, como quando localizam um documento como arquivo familiar, uma carta, por exemplo, mas não citam datas. 
12 Sobre o Centenário, é significativo do prestígio que o jurista usufruiu até a década de 60 a exposição organizada na Biblioteca Nacional em sua homenagem nessa efeméride, entre 28 de setembro e 10 de outubro de 1959. (Vide http://objdigital.bn.br/acervo_digital/div_iconografia/icon1285803.pdf Visitado em 27/07/2012.)

13 Noemia Paes Barreto BRANDÃO. Clovis Bevilacqua na intimidade. Rio de Janeiro: edição da autora, 1989, p. 9-14.

14 Idem, p. 11.

15 Idem, p. 15.

16 Sobre a produção literária de Amélia Beviláqua, também podem ser citados Algemira de Macedo MENDES. Amélia Beviláqua e Maria Firmina dos Reis na história da literatura: representação, imagens e memórias nos séculos XIX e XX. Tese de Doutorado em Linguística e Letras, PUCRS, 2006, Algemira de Macedo MENDES. Imagem da mulher na obra de Amélia Beviláqua. Rio de Janeiro: Caetés, 2004e Miridan Rejane Soares LIMA \& Pedro Pio FONTINELES FILHO. "Entre falas e silêncios da escrita: representações sociais e relações de gênero na obra de Amélia Beviláqua”, Comunicação em Semana de Iniciação Científica, Universidade Estadual do Piauí, 2010, Disponível em http://www.uespi.br/prop/XSIMPOSIO/TRABALHOS/ INICIACAO/Ciencias\%20Humanas $\% 20 \mathrm{e} \% 20$ Letras/ENTRE $\% 20$ FA L A S \% 20 E \% 20 SILENCIOS \% 20 D A \% 20 E S CR I T A \% 20 - \% 20 REPRESENTACOES\%20SOCIAIS\%20E\%20RELACOES\%20DE\%20 GENERO\%20NA\%20OBRA\%20DE\%20AMELIA\%20BEVILÁQUA.pdf Visitado em 21/11/2011..

17 Tal artigo foi publicado também na Revista da Academia Brasileira de Letras, de agosto de 1930, n. 104, com o título: "A Academia Brasileira de Letras e o futuro dicionário", p. 458-459. (Noemia Paes Barreto BRANDÃO. Clovis Bevilacqua na intimidade. Rio de Janeiro: edição da autora, 1989, p. 17). $O$ artigo versava sobre a discussão em relação à participação de mulheres na Academia Brasileira de Letras. Ver Alberto VENÂNCIO FILHO. "As mulheres na Academia", In: Revista Brasileira. Rio de Janeiro: Academia Brasileira de letras, Fase VII, out.-nov., Ano XIII, no. 49, 2006, pp. 7-44 e Michele Asmar FANINI. Fardos e Fardões: mulheres na Academia Brasileira de Letras (1897-2003). Tese de Doutorado em Sociologia, USP, 2009. Chama atenção o fato de que quando Júlia Lopes de Almeida teve seu nome excluído 
da lista final de sócios fundadores da ABL, em 1897, ou Carolina Michäelis não pôde ser sócia correspondente, em 1911, Clóvis Beviláqua não se manifestou contra a misoginia dos membros.

18 Noemia Paes Barreto BRANDÃO. Clovis Bevilacqua na intimidade. Rio de Janeiro: edição da autora, 1989, p. 19.

19 Gislene NEDER. "Amélia e Clóvis Bevilacqua: o casamento, o casal e a idéia de indivíduo." In: Anais, X Encontro Regional de História da ANPUH. UERJ, Rio de Janeiro, 14 a 18 de outubro de 2002, p. 11), reforçando a ideia de proximidade intelectual do casal, sugere que palestra proferida por Amélia, em 1905, no Congresso Scientífico Latino-Americano, realizado no Rio de Janeiro, e publicada em livro com o título "Instrução e Educação da Infância”, apresenta uma ligação umbilical com texto de Clóvis Beviláqua.

20 Noemia Paes Barreto BRANDÃO. Clovis Bevilacqua na intimidade. Rio de Janeiro: edição da autora, 1989, p. 22-5.

21 Gislene NEDER. Opus cit. pp. 7-8 levanta uma curiosa justificativa para a constante referência ao jurista como 'santo leigo', para além de seus hábitos simples, seu desapego material, sua falta de ambição arrivista ou o convívio cotidiano com animais domésticos: "A insistência com que os biógrafos destacam a 'santidade' de Clovis Bevilacqua revela, também, outro aspecto das lutas políticas e ideológicas na passagem à modernidade no Brasil. As lutas políticas pela implantação de um código civil no Brasil sempre esbarraram na resistência cultural, política, ideológica e afetiva, da Igreja e dos pensadores católicos brasileiros, inscritos desde o último quartel do século XIX no terceiro escolasticismo, neo-tomista. (...) As acusações de impiedade e anti-clericalismo que eram imputadas aos codificadores dos códigos civis (em Portugal e no Brasil; Visconde de Seabra, em Portugal foi muito atacado publicamente, sobretudo por Alexandre Herculano), fez com que os admiradores de Clovis Bevilacqua o protegessem com uma aura de sacralidade, exatamente para neutralizar os adversários das reformas e preservar no nome do civilista brasileiro."

22 Cabe referência a Vicentônio Regis Nascimento SILVA. Vossa Excelência, Vossa Senhoria, Excelentíssimo Senhor e Prezado Amigo: considerações sobre a correspondência de Clóvis Beviláqua. (Dissertação de Mestrado em História. UNESP Campus de Assis, 2009) dissertação de mestrado sobre o acervo de correspondências do jurista depositados no Memorial do Judiciário Cearense, no 
Tribunal de Justiça do Ceará, em Fortaleza. Somos levados a crer que Brandão trabalhou com outras missivas, tanto que se refere a cartas que estariam no Museu e no Arquivo do IAB (Vicentônio Regis Nascimento SILVA. Op. cit. nota 41, p. 39). Destacam-se entre a correspondência da juventude, de relações profissionais, as questões pessoais - o clientelismo, por exemplo, em correspondência defendendo interesses profissionais do amigo Afonso Cláudio, do cunhado Vitor Manuel ou de Antônio Alves da Fonseca (Noemia Paes Barreto BRANDÃO. Clovis Bevilacqua na intimidade. Rio de Janeiro: edição da autora, 1989, pp. 37-40). Também foram publicadas as cartas trocadas entre o ativista abolicionista e republicano Antônio Silva Jardim e o jurista cearense (Antônio SILVA JARDIM. Cartas a Clóvis Beviláqua. Rio de Janeiro: Gráfica Apolo, 1936).

23 Como a biógrafa busca retratar a intimidade do personagem, existem somente cartas que fariam parte da 'correspondência-rede' (que se destaca mais pela função do que pelo conteúdo, firmando relações de um grupo de forma vertical), estando ausentes as de 'correspondência-laboratório' (focada na finalidade intelectual baseada na horizontalidade do discutir, indicar, discordar e dialogar entre pares, discípulos e admiradores) (Michel TREBITSCH. "Correspondances d'intellectuells. Le cas des lettres d'Henri Lefebvre à Norbert Guterman (1935-1947)", In: Le Cahiers de l'IHTP, n.20, 1992).

24 Noemia Paes Barreto BRANDÃO. Clovis Bevilacqua na intimidade. Rio de Janeiro: edição da autora, 1989, p. 43.

25 SIQUEIRA (1995, p. 33-54) identifica como anteriores a Lyrio, que circulou entre 1902-1904, os seguintes periódicos voltados ao público feminino: A Mulher (1882), Ave Libertas (1885) e A Rosa (1890 a 1899).

26 Noemia Paes Barreto BRANDÃO. Clovis Bevilacqua na intimidade. Rio de Janeiro: edição da autora, 1989, p. 43-4.

27 Idem, p. 47.

28 Idem, p. 20-2.

29 Idem, p. 45.

30 Idem, p. 48.

31 Para minimizar a tensão da questão da origem do biografado, Brandão justifica a referência ao status de 'filho de padre' por ser fato já conhecido e a família ter autorizado a utilização de tal informação, além de apontar outros notáveis que tinham a mesma origem (José do Patrocínio, Nilo Peçanha, 
José de Alencar, Teodoro Sampaio, entre outros). (Noemia Paes Barreto BRANDÃO. Opus. Cit. p. 51)

32 Curiosamente, é aqui que sua descrição física como adulto é abordada, segundo relatos de Araripe Júnior, Martins Júnior e Alcântara Machado. (Noemia Paes Barreto BRANDÃO. Opus. Cit p. 53)

33 Barbosa Liam Sobrinho apud Noemia Paes Barreto BRANDÃO. Clovis Bevilacqua na intimidade. Rio de Janeiro: edição da autora, 1989, p. 63.

34 Noemia Paes Barreto BRANDÃO. Clovis Bevilacqua na intimidade. Rio de Janeiro: edição da autora, 1989, p. 68.

35 Alguns pensamentos de Clóvis Beviláqua, disponíveis a partir de cópia em caderno de Floriza, não são datados, mas se sobressaem os anos de 1936 e 1943.

36 "E a maior lição a se retirar da construção desses heróis na República Velha talvez seja a de que cultuar um herói não necessariamente implica adotar seus valores políticos e compartilhar sua visão básica de mundo. Provavelmente importa mais em um herói celebrá-lo enquanto tal do que realmente imortalizar suas idéias e bandeiras. É isso que permite a convivência fluida de vários heróis em um só politeísmo cívico: importa mais que sejam "grandes homens" do que sejam militaristas ou civilistas, do que concebam a civilização como empreendimento moral ou técnico, do que defendam a vida da metrópole ou a do sertão. Importa mais construir um amplo panteão do que dotá-lo de uma suposta coerência "ideológica". Indivíduos que em vida se opõem fortemente deixam de estar em conflito quando acedem à imortalidade. Aí, são só Grandes Homens, que encarnam valores diversos mas nunca incompatíveis. Seu culto os une a todos. É ingenuidade esperar dos cultuadores de um herói completa adesão ao pensamento e aos valores do ídolo.” (João Felipe GONÇALVES. "Enterrando Rui Barbosa: um estudo de caso da construção fúnebre de heróis nacionais na Primeira República”, In: Estudos Históricos, vol. 14, n 25, 2000, p. 160)

37 A confecção do Código Civil de 1917 recebe grande atenção na descrição da autora, que se utiliza de diversas citações de apoio à proposta de Clóvis Beviláqua frente às críticas de Rui Barbosa. (Noemia Paes Barreto BRANDÃO. Clovis Bevilacqua na intimidade. Rio de Janeiro: edição da autora, 1989, p 87-92)

38 Além de versado em Filosofia, Sociologia, História e Direito, o jurista era poliglota, com sólido conhecimento de latim e francês e compreensão 
de inglês, alemão, italiano, espanhol e rudimentos do tupi. (Noemia Paes Barreto BRANDÃO. Clovis Bevilacqua na intimidade. Rio de Janeiro: edição da autora, 1989, p. 84)

39 Destaque para, no Brasil, o IHGB e a ABL e, no exterior, para o Instituto de Coimbra, a American Academy of Political and Social Sciences, a Associação Internacional de Direito Comparado e a Associação Internacional de Filosofia do Direito.

40 Noemia Paes Barreto BRANDÃO. Clovis Bevilacqua na intimidade. Rio de Janeiro: edição da autora, 1989, p. 96-101.

41 Doença infecciosa aguda, causada por estreptococos, caracterizada por inflamação da pele e com sintomas como febre alta, tremores, mal-estar, náuseas, vômitos, entre outros.

42 Afecção inflamatória da garganta e da faringe, caracterizada por dificuldade mais ou menos intensa de deglutir e, por vezes, de respirar.

43 Noemia Paes Barreto BRANDÃO. Clovis Bevilacqua na intimidade. Rio de Janeiro: edição da autora, 1989, p. 103-06.

44 Brandão (Noemia Paes Barreto BRANDÃO. Opus cit. p. 109-111) elenca diversas manifestações a partir de diferentes instituições, governos estaduais e federal, o IHGB, a ABL, o IAB - Instituto de Advogados do Brasil, entre outras, mas omitiu a exposição na Biblioteca Nacional. No plano da cultura, o festival de panegíricos insere-se em uma tradição da época na qual o "exagero na avaliação da obra e a superficialidade das informações sobre a vida do escritor advêm de um compromisso da vida literária nas primeiras décadas do nosso século, quando o elogio do literato vitorioso socialmente era transformado numa performance que podia garantir também ao conferencista ou ao biógrafo um lugar no panteão da literatura nacional." (Maria Helena WERNECK. O Homem Encadernado: Machado de Assis na escrita das biografias. Rio de Janeiro: EdUERJ, 1996, p. 26)

45 Noemia Paes Barreto BRANDÃO. Clovis Bevilacqua na intimidade. Rio de Janeiro: edição da autora, 1989, p. 108.

46 Lana G. LIMA (Org.). Mulheres, Padres e Adúlteros: história e moral na sociedade brasileira. Rio De Janeiro: Dois Pontos, 1987; Kenneth P SERBIN. Padres, celibato e conflito social: uma história da Igreja Católica no Brasil. S. Paulo: Companhia das Letras, 2008; Gilberto FREYRE. Casa-Grande e senzala. Ed. Record. Rio de Janeiro: 1996; Ronaldo VAINFAS. Tropico dos pecados. Moral, sexualidade e Inquisição no Brasil. Rio de Janeiro: Ed. Campus, 1989; Eni Mesquita 
de SAMARA. As Mulheres, O Poder e a Família em São Paulo, século XIX. São Paulo: Marco Zero, 1989; Maria Adenir PERARO. Fardas, saias e batinas: A ilegitimidade na paróquia Senhor Bom Jesus de Cuiabá, 1853-90. Tese de doutorado, Universidade Federal do Paraná, Curitiba, 1997; Sheila Siqueira de Castro FARIA. Fortuna e família no cotidiano colonial (sudeste, século XVIII). Tese de Doutoramento, Universidade Federal Fluminense. Niterói. 1994; Eliane Cristina LOPES. Revelar o pecado: filhos ilegítimos na São Paulo do século XVIII. São Paulo: Annablume / FAPESP, 1998.

47 Ronaldo VAINFAS. Tropico dos pecados. Moral, sexualidade e Inquisição no Brasil. Rio de Janeiro: Ed. Campus, 1989, p. 87-92 e Kenneth P SERBIN. Padres, celibato e conflito social: uma história da Igreja Católica no Brasil. S. Paulo: Companhia das Letras, 2008, p. 61-63.

48 Ronaldo VAINFAS. Op.cit., p. 345 e Kenneth P SERBIN. Op. Cit., p. 74.

49 Kenneth P SERBIN. Op. cit, p. 73, aponta levantamentos que mostram que, na Bahia, no início do século XIX, 51\% dos padres reconheciam ter filhos, ao mesmo tempo em que o núncio papal acusava alguns padres brasileiros de manterem haréns.

50 Freyre (Gilberto FREYRE. Casa-Grande e senzala. Ed. Record. Rio de Janeiro: 1996, pp. 444-447) identifica na sociedade brasileira não só uma tolerância ímpar em relação aos filhos ilegítimos de religiosos, como ainda aponta a existência da expressão popular "feliz que nem filho de padre", sendo que as concubinas eram apresentadas como "comadres" e os filhos registrados como "filhos de pais desconhecidos" e, muitas vezes, chamados de "filhos adotivos" ou "sobrinhos".

51 Aliás, em 1827, Feijó, que teve cinco filhos, apresentou projeto de lei que extinguia o celibato clerical, argumentando que: 1) o celibato clerical não encontrava respaldo no Evangelho; 2) a Igreja primitiva permitia padres casados; 3) muitos padres nos primórdios da Igreja casaram-se após a ordenação; 4) a disciplina da Igreja em relação ao celibato tornara-se ao longo do tempo mais rígida, mas não era uniforme; 5) a Igreja Ortodoxa Grega permitia o casamento; e 6) a manutenção do celibato alimentava escândalos desnecessários. (Kenneth P SERBIN. Op. cit, p. 71-77)

52 Noemia Paes Barreto BRANDÃO. Clovis Bevilacqua na intimidade. Rio de Janeiro: edição da autora, 1989, p. 51.

53 Idem, pp. 59 e 63 
54 Trecho de carta copiado pela filha Floriza em caderno pessoal (Noemia Paes Barreto BRANDÃO. Op. cit., p. 13), infelizmente sem data.

55 Miridan Britto Knox FALCI. "Amélia de Freitas Beviláqua: A intelectual piauiense avançada”, disponível em www.fnt.org.br/dwp.php?a=b46d45af1e. pdfEid=109. Acessado em 21/11/2011

56 São obras de Amélia Beviláqua: "Alcyone - Bahia, 1902; Aspectos - Recife, 1906; Instrução e Educação da Infância - Recife, 1906; Através da Vida - Rio, 1906; Silhouettes - Rio, 1906; Literatura e Direito (em colaboração com Clóvis) - Bahia, 1907; Vesta - Rio, 1908; Angústia -Rio, 1913; Açucena - Rio, 1921; Jeannette - Rio, 1923; Milagre do Natal - Rio, 1928; Impressões - Rio, 1929; A Academia Brasileira de Letras e Amélia de Freitas Beviláqua - Rio, 1930; Flor do Orfanato - Rio, 1931; Divagações - Rio, 1931; Recordação do dia 7 de agosto de 1933 - Rio, 1933; Alma Universal - Rio, 1935”. (Miridan Britto Knox FALCI. “Amélia de Freitas Beviláqua: A intelectual piauiense avançada”, disponível em www.fnt.org.br/ dwp.php?a=b46d45af1e.pdfEid=109. Acessado em 21/11/2011., p. 3)

57 Noemia Paes Barreto BRANDÃO. Op.cit. p. 48.

58 Idem. p .108.

59 Silvio Meira MEIRA. Clóvis Beviláqua: sua vida, sua obra. Fortaleza: Edições Universidade Federal do Ceará, 1990, p. 111.

60 Miridan Britto Knox FALCI. "Amélia de Freitas Beviláqua: A intelectual piauiense avançada", disponível em www.fnt.org.br/dwp.php?a=b46d45af1e. pdfEid=109, p. 05. Acessado em 21/11/2011.

61 A Noite, 29-9-1932, apud Miridan Britto Knox FALCI. Opus. Cit. p. 5.

62 Miridan Britto Knox FALCI. Opus. Cit. p. 5-6.

63 Gislene NEDER. "Amélia e Clóvis Bevilacqua: o casamento, o casal e a idéia de indivíduo." In: Anais, X Encontro Regional de História da ANPUH. UERJ, Rio de Janeiro, 14 a 18 de outubro de 2002, pp. 11 e 14.

64 Pedro MAIA. O Mestre Clóvis Beviláqua. Rio de Janeiro: Laemmert, 1961, p. 5-6.

65 Idem, pp. 8 e 9.

66 Idem. p. 09.

67 Apud Andrea BORELLI. "Adultério e a mulher: considerações sobre a condição feminina no direito de família”, In: Caderno Espaço Feminino. v. 11, n. 14, Jan./Jul. 2004, p. 12-3. 
68 Sobre a polêmica envolvendo Clóvis Beviláqua, Eduardo Carneiro Ribeiro e Rui Barbosa, fizemos comunicação específica no XXV Congresso da Associação Latino-Americana de Sociologia (ALAS), em Porto Alegre. (Wilton C. L SILVA. "A linguagem e o Código Civil de 1916" In: Anais do XXV Congresso da Associacão Latinoamericana de Sociologia (ALAS), Porto Alegre, 2005)

69 Citando San Tiago Dantas, Martins identifica na réplica uma ação política diversionista "destinada a destruir o projeto Clóvis Beviláqua, substituindo-o por um de sua própria autoria (o que lhe daria a glória de ser o autor do Código Civil e o prazer da vingança contra Campos Sales e Epitácio Pessoa por haverem ultrajantemente confiado a empresa ao jurista cearense)."

70 Noemia Paes Barreto BRANDÃO. Clovis Bevilacqua na intimidade. Rio de Janeiro: edição da autora, 1989, p.85-92.

71 No caso do Código Civil de 1916, a contraposição da memória subterrânea à memória hegemônica permitiria pensar o contraste entre barbosistas e bevilaquistas, assim como a afirmação de dois modelos de ação política e jurídica: o de Clóvis Beviláqua, representante do criticismo da Escola de Recife, que se mostra desiludido com o modelo de República construído no país das oligarquias e de Vargas e que se exilou no reino do trabalho técnico e intelectual; e o de Rui Barbosa, representante do pragmatismo da faculdade de Direito de São Paulo, que na mesma situação inseriu-se como parte fundamental do sistema político na República Velha. O jurista baiano ocupou cargos no executivo e no legislativo federal e teve atuação decisiva na implantação da estrutura jurídico-institucional republicana na Constituição de 1891, no Código Criminal (1890) e na Lei do Registro e do Casamento Civil, também de 1890, instrumentos jurídicos que conjugavam um formalismo liberal com um caráter disciplinar e repressivo. Clóvis Beviláqua recusou diversos cargos públicos, dedicou-se mais à atividade intelectual do que à política, foi autor de um projeto de Código Civil bastante liberal e inovador (que perdeu algumas de suas características ao longo de mais de uma década de debates e disputas legislativas) e consultor do Ministério das Relações Exteriores na defesa dos interesses do país em contraste com os interesses externos (portanto, para além dos grupos locais). De algum modo, entre os advogados, Clóvis Beviláqua é referenciado enquanto jurista - inclusive pela influência que o Código Civil proposto por ele teve na prática cotidiana destes, e Rui 
Barbosa enquanto modelo de ação política. Falar de uma memória subterrânea sobre um indivíduo que ocupa relativa centralidade no imaginário de um grupo soa contraditório, mas se Clóvis Beviláqua ocupa uma posição relevante no panteão dos juristas nacionais, ao lado de outros destaques, sua figura enquanto literato e pensador esvaneceu-se por completo.

72 O relato de Brandão, por exemplo, oferece uma particularidade - a visão da intimidade do biografado - justamente pelo fato de a autora ser filha de amigo próximo de Clóvis Beviláqua e assim ter lembranças deste e vínculos afetivos com as filhas do biografado. 